\title{
Laparotomy for perforated small bowel from ingested paperclips
}

\author{
Ishaan Maitra, ${ }^{1}$ Emma Watts, ${ }^{2}$ Ashok Menon, ${ }^{1}$ Nigel Scott ${ }^{3}$
}

1 Department of Upper Gl Surgery, North West Deanery, Royal Preston Hospital, Preston, UK

${ }^{2}$ Royal Preston Hospital, Preston, UK

${ }^{3}$ Department of Colorectal Surgery, Royal Preston Hospital, Preston, UK

\section{Correspondence to} Ishaan Maitra, ishaan.maitra@googlemail.com

\section{DESCRIPTION}

Eighty to $90 \%$ of ingested foreign bodies which reach the stomach will pass uneventfully through the gastrointestinal tract. ${ }^{1-3}$ One per cent may require a surgical procedure as $10 \%$ can be removed endoscopically. ${ }^{3}$ The risk of complications including perforation, obstruction and haemorrhage is increased with long sharp metal objects, and may be higher in patients with adhesions due to prior abdominal surgery. ${ }^{1}$

Objects less than $6 \mathrm{~cm}$ in diameter can pass through the pylorus of the stomach and can theoretically cause small bowel obstruction and/or perforation. ${ }^{2}$ This report describes a 22-year-old male prisoner who previously ingested steel paperclips deliberately straightened out before swallowing which subsequently caused small bowel perforation.

Postingestion, he reported of diffuse central abdominal pain and a conservative approach was taken initially using intravenous antibiotics and fluids. Three days after admission his pain worsened and a CT scan with contrast was performed. This showed paperclip penetration through small bowel loops, with a $2.5 \mathrm{~cm}$ collection in the small bowel mesentery deep to these clips.

A laparotomy was performed and multiple straightened paperclips were found extruding through the jejunal wall resulting in two enteroenteral fistulae and free perforation into an abscess cavity (see figures 1 and 2).

The collections were drained and all clips were removed using intraoperative X-ray imaging. The perforated segment of bowel containing the main mass of straightened paperclips was removed with small bowel reanastamosis (minimal peritoneal contamination). He was well enough for discharge 5 days later without any postoperative complications.

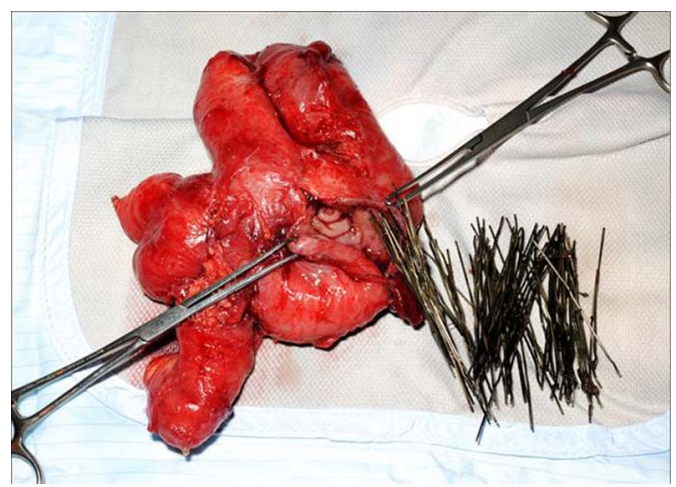

Figure 1 Straight rigid paperclips and perforated jejunum

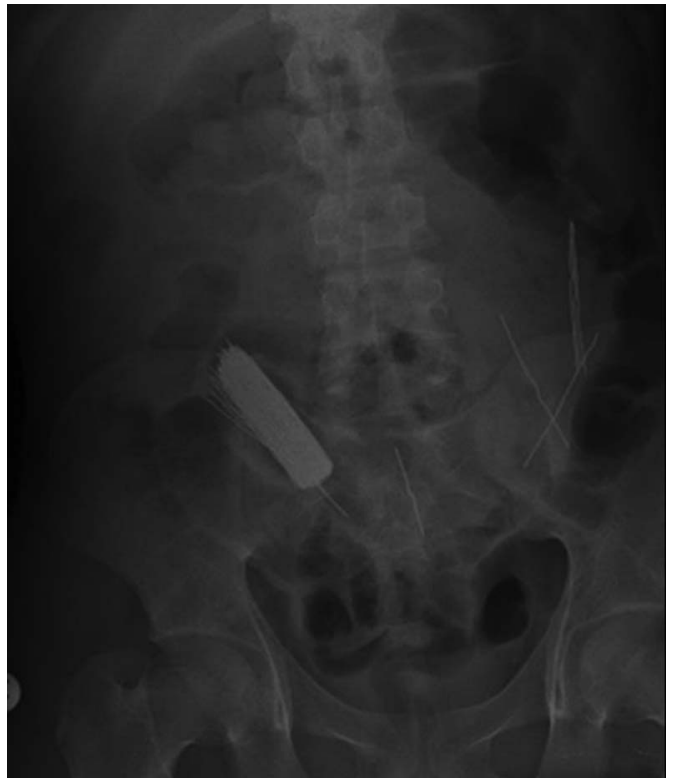

Figure 2 Plain radiograph showing multiple locations of paperclips in small bowel-main site of perforation.

\section{Learning points}

- Jejunal perforations are relatively rare.

- No generalised consensus of how to treat foreign body ingestion greater than $6 \mathrm{~cm}$ paperclips $6.7 \mathrm{~cm}$ in length.

- Surgery may be indicated where sepsis develops in the presence of persistent foreign bodies in the small bowel.

Acknowledgements Mr Nigel Scott, Mr Ashok Menon and Dr Emma Watts Royal Preston University Hospital, Radiology Department, Royal Preston University Hospital, Medical Photography Department.

Contributors Mr Scott operated case. Operators: Mr Scott, AM, IM consent obtained by EW.

Competing interests None.

Patient consent Obtained.

Provenance and peer review Not commissioned; externally peer reviewed.

\section{REFERENCES}

1 Voinovskii AE, Azarov GV, Koliadenkova TG, et al. The diagnostics and treatment of the foreign bodies of the gastrointestinal tract. Khirurgiia (Mosk) 2012;8:51-4.

2 Elsen GM, Baron TH, Dominitz JA, et al. Guideline for the management of ingested foreign bodies. Gastrointest Endosc 2002;55:802-6.

3 Stack LB, Munter DW. Foreign bodies in the gastrointestional tract. Emerg Med Clin North Am 1996;14:493-521. 
Copyright 2013 BMJ Publishing Group. All rights reserved. For permission to reuse any of this content visit http://group.bmj.com/group/rights-licensing/permissions.

BMJ Case Report Fellows may re-use this article for personal use and teaching without any further permission.

Become a Fellow of BMJ Case Reports today and you can:

- Submit as many cases as you like

- Enjoy fast sympathetic peer review and rapid publication of accepted articles

- Access all the published articles

- Re-use any of the published material for personal use and teaching without further permission

For information on Institutional Fellowships contact consortiasales@bmjgroup.com

Visit casereports.bmj.com for more articles like this and to become a Fellow 